\title{
METODE DAKWAH MUHAMMADIYAH DI KABUPATEN TAPANULI SELATAN
}

\author{
MOHD. RAFIQ \\ Lecturer of Da'wa and Communications Faculty at IAIN Padangsidimpuan \\ Jl. T. Rizal Nurdin Km. 4.5 Sihitang Padangsidimpuan 22733 \\ Email: Mohd.rafiqsma@gmail.com
}

\begin{abstract}
To actualize a successfull da'wa, Muhammadiyah has formulated various methodologies appropriately to the people in their lifes. For the first work, Muhammadiyah eradicates hard the three aspects; takhyul, bid'ah, and khurafat. Da'wa of Muhammadiyah is intended to restore the understanding and practicing of Islam rules based on the Qur'an and Sunnah. The successfull of da'wa which is characterized by the practice of Islam in the mental and spritual aspects can be reached when the methodology of da'wa can be accepted by the people. There are several methods of da'wa applied by Muhammadiyah in South Tapanuli; they are al hikmah, Al mau'izhatil hasanah, and mujadalah. The three methods implemented in da'wa bil lisan, da'wa bil kitabah, da'wa bil hal and da'wa cultural. Although in implementing them Muhammadiyah faces hard chalenges from many people, it keeps trying to restore the understanding and practicing of Islam rules based on $A l^{\prime} Q u r^{\prime}$ an and Sunnah.
\end{abstract}

Keywords: Methods Da'wa, Muhammadiyah, understanding and practicing of Islam rules

\section{Abstrak}

Untuk mewujudkan keberhasilan dakwah Muhammadiyah telah merumuskan berbagai metodologi yang dianggap layak untuk diaplikasikan dalam kehidupan masyarakat. Pada tahap awal, Muhammadiyah sangat gencar memberantas masalah takhyul, bid'ah dan khurafat. Dakwah ditujukan untuk mengembalikan pemahaman dan pengamalan ajaran Islam berdasarkan petunjuk Alquran dan Sunnah. Keberhasilan dakwah yang ditandai dengan pengamalan ajaran Islam pada aspek mental dan spritual baru akan dapat tercapai apabila metodologi yang digunakan dapat diterima masyarakat. Ada beberapa metode dakwah yang diterapkan muhammadiyah di Tapanuli Selatan yaitu; metode al hikmah, Al mau'izhatil hasanah, dan mujadalah. Ketiga metode dakwah tersebut diterapkan dalam bentuk dakwah bil lisan, dakwah bil kitabah, dakwah bil hal dan dakwah cultural. Walaupun dalam pelaksanaannya mendapat tantangan yang sangat keras ditengah masyarakat, Muhammadiyah terus berusaha untuk mengembalikan pemahanan masyarakat pengamalan ajaran Islam berdasarkan petunjuk Alquran dan Sunnah.

Kata Kunci: Metode Dakwah, Muhammadiyah, pemahaman dan pengalaman ajaran Islam. 


\section{PENDAHULUAN}

Muhammadiyah merupakan salah satu organisasi Islam terbesar di Indonesia. Organisasi ini didirikan oleh K.H. Ahmad Dahlan pada tanggal 8 Zulhijjah $1330 \mathrm{H}$ bertepatan dengan tanggal 18 November 1912 di Yogyakarta. Dibanding dengan organisasi-organisasi Islam lainnya seperti Nandlatul Ulama, Persis, Al-Irsyad, maka. Muhammadiyah termasuk organisasi Islam tertua di Indonesia.

Seiring dengan rentang waktu perjalanannya, hingga saat ini Muhammadiyah telah melakukan berbagai upaya pengembangan Islarn termasuk melakukan gerakan reformasi pemahaman Islam dalam kehidupan masyarakat. Adalah wajar bila Peacock memandang Muhammadiyah sebagai gerakan reforrnasi Islam yang terkuat di Asia Tenggara, malah tidak menutup kemungkinan terkuat di seluruh dunia Islam ${ }^{1}$.

Dalam Anggaran Dasar Muhammadiyah dinyatakan bahwa oraganisasi Muhammadiyah merupakan gerakan dakwah Islam amr ma'ruf nahy munkar yang bertujuan untuk menegakkan dan menjunjung tinggi agama Islam sehingga terwujud masyarakat Islam yang sebenar-benarnya ${ }^{2}$. Berdasarkan ini, tampak jelas bahwa Muhammadiyah sangat concern dalam melakukan pengembangan dakwah Islam sehingga terwujud kehidupan masyarakat Islam yang sebenar-benarnya seperti diisyaratkan Alquran dengan kehidupan yang penuh dengan nuansa kesejahteraan serta memperoleh ampunan dari Allah (baldatun tayyibatun wa rabun gafur).

Untuk mewujudkan keberhasilan dakwah itu, Muhammadiyah telah merumuskan berbagai metodologi yang dianggap layak untuk diaplikasikan dalam kehidupan masyarakat. Pada tahap awal, Muhammadiyah sangat gencar memberantas masalah takhyul, bid'ah dan khurafat. Dakwah ditujukan untuk mengembalikan pemahaman dan pengamalan ajaran Islam berdasarkan petunjuk Alquran dan Sunnah33.

Dakwah Islam yang disampaikan pada fase awal itu tidak begitu saja diterima dengan mudah oleh masyarakat. Muhammadiyah mendapat tantangan keras dari masyarakat yang sudah mapan melaksanakan ketiga praktek ajaran Islam tersebut. Meskipun demikian, Muhammadiyah terus berupaya mencari formulasi metodologi dakwah yang tepat sehingga masyarakat menyadari kekeliruannya dan bersedia kembali kepada ajaran Islam murni sesuai dengan pedoman Alquran dan Sunnah.

Muhammadiyah menyadari betul bahwa dakwah harus disampaikan secara tepat dan komunikatif agar benar-benar berhasil. Keberhasilan dakwah yang ditandai dengan pengamalan ajaran Islam pada aspek mental dan spritual baru akan dapat tercapai apabila metodologi yang digunakan dapat diterima masyarakat. Sebab dalam kajian

\footnotetext{
1. James L. Peacock, Gerakan Muahmmadiyah Memurnikan Ajaran Islam (Jakarta: Citra kreatif, 1986), h. 5

2 Pimpinan Pusat Muhammadiyah, Anggaran Dasar dan Anggaran Rumah Tangga Muhammadiyah (Yogyakarta: PP. Muhammadiyah, 2002), h. 3.

${ }^{3}$ Yusuf Abdullah Puar, Pejuangan dan Pengabdian Muhammadiyah (Jakarta: Pustaka Antara, 1989), h. 
dakwah, sangat perlu diperhatikan interaksi masing-masing unsur dakwah khususnya antara $d a^{\prime} i$ (penyampai), mad'u (masyarakat) serta metode yang digunakan ${ }^{4}$. Itulah sebabnya Muhammadiyah pada tahun-tahun belakangan ini gencar mengkampanyekan pelaksanaan metode dakwah Dakwah kultural ini dimaksudkan untuk melakukan pendekatan kultur (budaya) masyarakat, sehingga dakwah dengan mudah dipahami, diterima dan diewejantahkan dalam kehidupan sehari-hari.

Sebagai organisasi dakwah yang telah lama berkiprah di Kabupaten Tapanuli Selatan, Muhammadiyah telah berupaya menggagas berbagai metode dakwah yang tepat untuk turut ambil bagian dalam pengembangan Islam bagi masyarakat Muslim di Tapanuli Selatan. Berdasarkan ini, menarik untuk diteliti bagaimana sesungguhnya metode dakwah yang dikembangkan oleh Muhammadiyah sebagai gerakan amr ma'ruf nahy munkar di Kabupaten Tapanuli Selatan, dan bagaimana pula efektifitasnya dalam pengembangan ajaran Islam di daerah ini. Untuk itu peneliti berupaya menelaah lebih lanjut permasalahan tersebut dan menuangkannya dalam bentuk penelitian yang diberi judul "Metode Dakwah Muhammadiyah di Kabupaten Tapanuli Selatan".

Berdasarkan uraian latar belakang di atas, maka masalah-masalah yang hendak diteliti dalam penelitian ini adalah sebagai berikut:

1. Metode dakwah apa saja yang diterapkan Muhammadiyah di Kabupaten Tapanuli Selatan?

2. Bagaimana efektifitas pelaksanaan metode dakwah Muhammadiyah di Kabupaten Tapanuli Selatan?

Penelitian ini secara urnum bertujuan untuk mengkaji metode dakwah Muhammadiyah dan upaya pengembangannya di tengah masyarakat Muslim Kabupaten Tapanuli Selatan. Secara khusus, penelitian ini ditujukan untuk menjawab permasalahan sebagaimana tertera dalam rumusan masalah di atas, yaitu:

1. Untuk menguraikan metode dakwah yang dilakukan Muhammadiyah pada masyarakat Muslim di Kabupaten Tapanuli Selatan.

2. Untuk mendeskripsikan efektifitas pelaksanaan metode dakwah Muhammadiyah di Kabupaten Tapanuli Selatan.

\section{METODE PENELITIAN}

Penelitian ini bersifat deskriptif analitis, yaitu penelitian yang menggambarkan keadaan objek penelitian pada saat penelitian dilakukan, berdasarkan data dan fakta yang tampak atau sebagaimana adanya ${ }^{5}$. Untuk memberikan bobot yang lebih tinggi pada metode ini, maka data atau fakta yang ditemukan, dianalisa dan disajikan secara sistematis sehingga dapat lebih mudah untuk dipahami dan disimpulkan. Sejalan dengan

${ }^{4}$ Abdulah Rosyad Shaleh, Manajemen Dakwah (Jakarta: Pustaka 1977), h. 18

5 Hadary Nawawi Dan Mimi Martini, Penelitian Terapan (Yogyakarta:Gajah Mada University Press,1996),h.73 
sifat penelitian diskriptif, maka pendekatan yang digunakan dalam penelitian ini adalah kualitatif ${ }^{6}$. Seluruh rangkaian cara kerja atau proses penelitian ini berlangsung secara serempak (simultan) dilakukan dalam bentuk pengumpulan, pengolahan dan menginterpretasikan sejumlah data atau fakta yang ada, dan selanjutnya disimpulkan dengan metode induktif. Adapun sumber data penelitian ini terdiri dari dua sumber, yakni primer dan sekunder. Sumber data primer diperoleh dari informan penelitian melalui observasi dan wawancara mendalam, dan Sumber data sekunder diperoleh dari sejumlah dokumen, seperti dari Badan Pusat Statistik (BPS) Kabupaten Tapanuli Selatan; dokumen resmi Muhammadiyah; sumber bacaan pendukung (literatur) baik buku-buku yang relevan dengan pembahasan penelitian maupun hasil-hasil penelitian yang telah ada sebelumnya.

Pengumpulan data primer dilakukan secara bertahap dengan menggunakan alat pengumpulan data observasi dan wawancara mendalam. Sedangkan wawancara mendalam dilakukan kepada informan penelitian untuk menggali informasi tentang metode dakwah Muhammadiyah di Kabupaten Tapanuli Selatan. Sedangkan untuk mendapatkan data sekunder, peneliti menggunakan teknik pengumpulan data dokumentasi dan studi pustaka dengan instrumen ceklis, untuk memperoleh berbagai informasi atau data pelaksanaan metode dakwah Muhammadiyah di Kabupaten Tapanuli Selatan. Analisis data dimulai sejak proses pengumpulan data. Setiap informasi disilang melalui komentar subjek yang berbeda untuk menggali informasi dalam wawancara dan observasi lanjutan, Temuan observasi mengenai pelaksanaan dan efektifnya metode dakwah di suatu tempat, diuji melalui komentar subjek lain di tempat yang sama atau tempat lain, begitu juga mengenai pendapat da'i diuji dengan pendapat dai Muhammadiyah lainnya, sehingga lebih objektif dan akurat. Selanjutnya data dikategorisasi sesuai kebutuhan penelitian. Kepada masyarakat Muslim, anggota Muhammadiyah, da'i, dan tokoh-tokoh dakwah juga dimintai komentar tentang metode dakwah Muhammadiyah yang telah berlangsung di Kabupaten Tapanuli Selatan. Analisis dilakukan melalui penyaringan data, penggolongan dan penyimpulan serta uji ulang. Setiap interpretasi logis, jika memerlukan analisis statistik dapat dilakukan sepanjang bisa mendukung dan memperjelas interpretasi. Data yang terkumpul selanjutnya disaring dan disusun dalam kategori-kategori dan saling dihubungkan, Melalui proses inilah penyimpulan dibuat ${ }^{7}$. Tujuannya adalah untuk memperkokoh dan memperluas bukti yang dijadikan landasan pengambilan kesimpulan tersebut. Pengujian dilakukan terhadap interpretasi bab-bab sebelumnya di dalam uraian logis atau kausal untuk memperoleh bukti penguat kesimpulan dari berbagai sumber. Dengan demikian, seluruh bab laporan merupakan kesatuan bahasan sistematis.

${ }^{7}$ Matthew Miles dan A. Michel Huberman, Analisis Data Kualitatif (Jakarta: UI Press, 1992), h. 15-16 


\section{HASIL PENELITIAN DAN PEMBAHASAN}

\section{Metode Dakwah Muhammadiyah di Kabupaten Tapanuli Selatan}

Dakwah merupakan kegiatan penting dalam menjaga kelangsungan kehidupan ajaran Islam di muka bumi. Tanpa dakwah, besar kemungkinan ajaran suci ini akan lenyap dan terlupakan orang. Islam mewajibkan setiap umatnya untuk menjadi da'i kapan saja, di mana saja dan pada siapa saja. Dengan demikian dakwah bukanlah semata-mata timbul dari pribadi atau golongan saja, tetapi setidak-tidaknya harus ada golongan yang melaksanakannya.

Secara filosofis, orientasi dakwah adalah proses mempertemukan antara fitrah dan wahyu. Untuk menjadi Muslim seutuhnya diperlukan proses dakwah untuk menyampaikan, menyerukan dan mensosialisasikan nilai-nilai Islam dalam segala aspeknya yang bersumber dari Alquran dan as-Sunnah. Keyakinan (akidah) mempermudah berlangsungnya dakwah sebagai proses internalisasi dan sosialisasi nilai-nilai Islam. Dalam pelaksanaannya, dakwah merupakan aktualisasi imani (teologis) yang dimanifestasikan dalam suatu sistem kegiatan manusia beriman dalam bidang kemasyarakatan, dilaksanakan secara teratur, untuk mempengaruhi cara berfikir, merasa dan bersikap serta bertindak sehingga terwujud ajaran Islam dalam segala aspek kehidupan ${ }^{8}$.

Masyarakat Islam yang diwujudkan melalui sistem dakwah adalah masyarakat yang berkembang dengan menjalankan syariat Islam secara integral dan komprehensif yang menampilkan watak egalitarian, berkeadilan dan penuh kasih sayang. Dalam kenyataannya, dakwah Islam senantiasa bersentuhan dengan realitas sosial yang mengitarinya. Akibat kondisi seperti itu maka ada dua kemungkinan yang mungkin terjadi. Pertama, dakwah Islam mampu memberikan output (hasil atau pengaruh) terhadap lingkungan dalam arti memberi dasar filosofi, arah, dorongan dan pedoman perubahan masyarakat sampai terbentuknya realitas sosial baru yang diinginkan. Kedua, dakwah Islam dipengaruhi oleh perubahan masyarakat dalam arti eksistensi, corak dan arahnya. Ini berarti aktualitas dakwah ditentukan oleh sistem sosio kultural. Pada gilirannya, dakwah Islam bisa saja bersifat statis dan juga berlangsung secara dinamis.

Pengerahan segala potensi sumber daya yang ada dalam aktivitas dakwah untuk mencapai tujuan yang telah ditetapkan merupakan suatu proses. Dengan kata lain dakwah yang fungsional, terpadu, komprehensif dan berkesinambungan hanya bisa terlaksana manakala dilakukan dengan memperhatikan segenap unsur-unsur yang melingkupi penyelenggaraan dakwah.

Dasar-dasar manajemen penyelenggaraan dakwah ini semakin penting peranannya sebagai kemampuan dan keterampilan mengembangkan serta

${ }^{8}$ Amrullah Ahmad. Dakwah Islam dan Perubahan Sosial (Yogyakarta: Prima Duta, 1989), h. 2 
menggerakkan potensi dakwah Islam yang di masyarakat dewasa ini. Sebab jalan dakwah itu sendiri sangat luas dan mencakup semua aspek kehidupan umat Islam. Dakwah bisa saja menggunakan metode pidato, ceramah, fatwa dan sebagainya. Dapat pula menggunakan daya kekuasaan untuk mengubah kemunkaran dan bisa juga menggunakan tulisan di majalah, buku-buku kemudian menyebarluaskannya. Mendirikan yayasan, mengadakan pertemuan ilmiah di lembaga-lembaga Islam, masjid-masjid, perkumpulan pengajian bahkan di lapangan-lapangan serta di berbagai kesempatan ${ }^{9}$.

Untuk menjadikan dakwah sebagai proses pelembagaan ajaran Islam peranan da'i dan metode yang digunakan sangat strategis, sebab da'i sebagai penyampai risalah Islam kepada masyarakat merupakan perancang dan pengelola dakwah yang pada gilirannya mengarahkan perubahan perilaku masyarakat menuju perbuatan yang Islami. Sedangkan metode yang digunakan merupakan kunci sukses atau gagalnya usaha untuk membentuk masyarakat Islam yang paripurna itu ${ }^{10}$.

Muhammadiyah mengakomodasi sistem organisasi untuk mewujudkan masyarakat utama. Masyarakat utama dipandang sebagai realitas duniawi yang hanya bernilai jika ditempatkan sebagai media pengabdian pada Tuhan. Berdasarkan itu, Muhammadiyah memandang kehidupan sosial adalah 'sunnatullah' sebagai cermin kehendak Sistem dan tata aturan masyarakat, harus merupakan realisasi hukum Allah yang tersusun dalam syariah. Dari sisi ini, kegiatan sosial adalah ibadah atau ritual kepada Tuhan, keterlibatan seseorang di dalam organisasi seperti Muhammadiyah, hukumnya wajib. Ketidaktaatan terhadap organisasi bisa berarti pelanggaran aturan Tuhan. Seluruh kegiatan sosial dalam Muhammadiyah merupakan dakwah dengan tujuan membawa seluruh masyarakat Muslim kepada ajaran Islam yang murni. Pandangan seperti ini dapat dikaji dari beberapa dokumen resmi Muhammadiyah, antara lain dalam Mukaddimah Anggaran Dasar Muhammadiyah ${ }^{11}$. Dalam dokumen ini dapat dilihat maksud tentang masyarakat utama yang di idam-idamkan oleh organisasi Muhammadiyah.

\section{a. Metode dakwah bil lisan}

Berdasarkan hasil penelitian terungkap, bahwa metode dakwah yang dominan digunakan da'i di Kabupaten Tapanuli Selatan adalah metode dakwah bil lisan (ceramah dan diskusi). Metode ceramah yang berlangsung hingga saat ini bergerak dari rumah ke rumah. Tempatnya diatur secara bergilir di rumah anggota pada setiap hari Rabu (malam Kamis). Seluruh peserta duduk bersila di

\footnotetext{
${ }_{9}^{9}$ M. Yusuf Musa. Al-Qur'an dan Falsafah, terjemahan Ahmad daudy (Jakarta: Bulan Binatang,1988), h. $86-87$

${ }^{10}$ Fathi Yaqan. Menuju Kepada Islam, diterjemahkan Chadijah Nasution (Jakarta: Bulan Bintang,1978),

11 Lihat Anggaran Dasar \& Rumah Tangga Muhammadiyah, Hasil Keputusan Muktamar Muhammadiyah ke-45 Malang Jawa Timur (3-8 Juli 2005)
} 
lantai membentuk lingkaran, dimana da'i atau guru ngaji mengambil posisi di tengah mata rantai lingkaran itu, menyampaikan ceramah dan seluruh peserta mendengar. Topik pengajian ditentukan oleh da'i atau atas kesepakatan bersama dan program organisasi. Pengajian dilakukan dengan lebih dahulu semua peserta secara bersama-sama membaca Alquran. Isi ceramah sering tidak terkait dengan ayat-ayat Alquran yang dibaca.

Setelah salat isya, peserta mengalir menuju tempat pengajian. Tepat pukul 20.00, pengajian dirnulai, dipimpin moderator yang mengawali mengucap salam, kemudian mengajak peserta membaca basmalah. Di antara peserta ada yang membaca beberapa ayat Alquran ditirukan oleh peserta lainnya, sesudah itu moderator mempersilahkan dai atau guru ngaji memulai cerarnah. Tidak ada tanda khusus bagi dai, seperti peci atau surban. Setelah mengucap salam, da'i memulai ceramah dengan doa singkat berbahasa Arab, membaca satu atau dua ayat Alquran atau hadis, kadang disertai nama surat dan nomor ayat atau sanad dan perawi hadis, namun sering juga tidak. Isi ceramah adalah maksud ayat Alquran atau hadis atau berbagai aspek syariah.

Bahan ceramah jarang diambil dari kitab kuning, buku tarjih atau keagamaan lainnya. Selama ceramah, da'i hampir tidak pernah menyebut pendapat ulama atau pimpinan Muhamrnadiyah. Sesudah 30-45 menit, dibuka tanya jawab, walaupun peserta jarang bertanya. Pengajian ditutup pukul 21.00 dengan membaca "alhamdulillahir rabbil 'alamiin". Sebelum atau sesudah itu, disampaikan pengumuman pengajian berikut, kegiatan organisasi dan infak yang diperoleh dengan rincian penggunaan.

Sesudah resmi ditutup, tuan rumah mengeluarkan makanan ringan sebagai hidangan penutup setelah teh atau kopi. Biaya konsumsi diambil dari infak sebelumnya, namun lebih banyak merupakan infak tuan rumah. Karena itu, jenis makanan hingga menu tergantung tuan rumah. Beberapa peserta, terlihat masih 'ngobrol' dan yang lain pamitan dengan mengucap salam, sama ketika mereka bertemu satu sama lain. Pagi berikutnya, anggota Muhammadiyah bekerja seperti umumnya anggota masyarakat lain. Pada umumnya pekerjaan mereka adalah pedagang (wiraswasta). Rumah mereka tersebar di tengah-tengah penduduk bukan pengikut, sehingga pengajian tampak menjadi identitas sosial.

\section{b. Metode Dakwah Kultural}

Penggunaan metode dakwah kultural juga sangat kentara dalam aktivitas sosial keagamaan Muhammadiyah di Kabupaten Tapanull Selatan. Bagi Muhammadiyah, dakwah kultural dianggap sebagai strategi dakwah melalui gerakan budaya dan perubahan sosial di tengah masyarakat Muslim. Melalui dakwah kultural Muhammadiyah melakukan ikhtiar terus menerus untuk 
mewujudkan Islam sebagai agama yang membawa kebahagiaan hidup umat manusia di dunia dan akhirat secara simultan ${ }^{12}$.

Dakwah kultural sebagai sebuah proses antara lain merupakan proses komunikasi sekaligus sebagai upaya untuk pemecahan masalah dan pengembangan masyarakat yang dibingkai oleh Islami. Sebagai proses komunikasi, dakwah kultural dapat menjadikan budaya lokal menjadi wahana dalam mendekati masyarakat sebagai sasaran dakwah sehingga seluruh lapisan dan kelompok masyarakat dapat menjadi umat dakwah. Dakwah Muhammadiyah dalam konteks budaya lokal berarti di satu pihak, bagaimana terdapat pemahaman dan upaya yang lebih empatik dalam mengapresiasi kebudayaan masyarakat, dan di pihak lain bagaimana mengaktualisasikan ajaran Islam secara terus menerus dan berproses sehingga nilai-nilai Islam mempengaruhi, membingkai dan membentuk kebudayaan yang Islami ${ }^{13}$.

Ciri-ciri dakwah kultural adalah dinamis, kreatif dan inovatif. Dalam konteks sejarah Islam, ketiga ciri dakwah kultural ini pernah dipraktekkan oleh Rasulullah saw, terutama ketika memperlakukan Tsumamah bin Utsal, kepala suku Bani Hanifah, di saat menjadi tawanan umat Islam. Selama beberapa hari, setiap pagi Nabi Muhammad saw menjamu dengan susu ontanya sebagai penghormatan terhadap kedudukan sosial Tsumamah. Walaupun tetap congkak dan menunjukkan permusuhan, Tsumamah dibebaskan tanpa syarat. Tsumamah tidak bergegas kembali ke kaumnya, tapi bersuci dan menyatakan masuk Islam. Sikap Nabi saw ini merupakan contoh dari kreativitas kultural dalam berdakwah 14 .

Kreativitas dan inovasi kultural dalam berdakwah juga dilakukan oleh K.H. Ahmad Dahlan dengan mendirikan lembaga pendidikan, rumah sakit, panti asuhan dan lain-lain. Ini semua adalah contoh penting bahwa K.H. Ahmad Dahlan dalam berdakwah menggunakan pendekatan kultural. Pendekatan ini diteruskan oleh para elit Muhammadiyah dalam tempo singkat berkembang pesat. Dakwah kultural dengan demikian memperhatikan tiga dimensi, yaitu dimensi kerisalahan, dimensi kerahmatan, dan dimensi kesejarahan. Secara substansial, misi dakwah kultural adalah upaya melakukan dinamisasi dan purifikasi. Dinamisasi bermakna sebagai kreasi budaya yang memiliki kecenderungan untuk selalu berkembang dan berubah ke arah yang lebih baik dan Islami. Sedangkan purifikasi berarti usaha pemurnian nilai-nilai dan budaya dengan mencerminkan nilai-nilai. tauhid. Ajaran Islam mengandung pesan

12 Pimpinan Pusat Muhammadiyah, Dakwah Kultural Muhammadiyah (Yogyakarta:Suara Muhammadiyah,2004), h.4.

${ }^{13}$ Ibid., h. 34-35

${ }^{14}$ Ibid., h-29-30 
tentang kehidupan universal bagi semua umat manusia baik Muslim maupun non-Muslim. Sebagaimana ditegaskan oleh Alquran dalam surah Saba ayat 28:

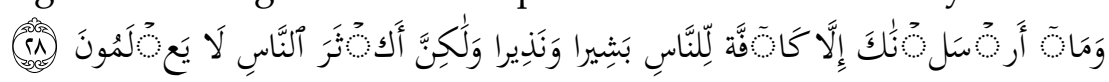

Artinya: "Dan Kami tidak mengutus kamu, melainkan kepada umat manusia seluruhnya sebagai pembawa berita gembira dan sebagai pemberi peringatan, tetapi kebanyakan manusia tiada mengetahui"15.

Islam juga menganjurkan kearifan dalam memahami realitas masyarakat yang sifatnya ma'ruf, dan mencegah kemunkaran dengan memperhatikan keadaan dan kecenderungan manusia beserta sifat dan karakternya. Keadaan dan kecenderungan manusia secara individual maupun kolektif menjadi pertimbangan dasar bagi dakwah Islam sebagai proses yang saling mempengaruhi antar individu, individu dengan kelompok, dan antar kelompok yang melibatkan aspek-aspek dinamika pemahaman dan kesadaran, penolakan dan penerimaan, kejumudan dan perubahan.

Islam membutuhkan kebudayaan dalam rangka menyebarkan misimisinya baik yang berupaya adat, tradisi, seni dan aspek-aspek kebudayaan lainnya. Namun keduanya perlu dibedakan dengan tegas, mana Islam sebagai agama tauhid yang bersifat universal, absolut dan abadi; dan mana Islam budaya yang bersifat partikular, relatif, dan temporal sebagai bagian dari kreasi manusia sekaligus merupakan ekspresi keislaman dalam kenyataan hidup para pemeluknya.

Oleh karena itu, dakwah Islam merupakan proses yang saling mempengaruhi diimplementasikan secara arif (hikmah), terbuka dan dialogis dan manusiawi. Dakwah Islam dilakukan sebijaksana mungkin dengan memperhitungkan situasi dan kondisi objek dakwah, baik kemampuan intelektual masyarakat maupun kondisi psikologi perkembangan mereka. Muhammadiyah memandang bahwa objek dakwah itu plural (majemuk), ada kelompok masyarakat yang disebut santri, abangan, priyayi, tradisionalis, modernis, sinkretik, lokal maupun global. Kemajemukan ini merupakan proses sosial budaya yang dapat berubah searah perubahan kehidupan sosial, ekonomi, budaya dan nilai-nilai tertentu baik secara khusus maupun universal.

Kemajemukan itulah yang mendorong Muhammadiyah melakukan dakwah dengan pendekatan atau metode yang tepat. Dalam kaitan ini terkandung makna bahwa dakwah berarti menyampaikan Islam dalam bahasa dan kebudayaan masyarakat setempat. Sebagaimana dinyatakan dalam Alquran surah Ibrahim ayat 4:

${ }^{15}$ Departemen Agama RI, Al-Qur'an dan Terjemahanya (Semarang: Toha Putra 1989), h.688. 


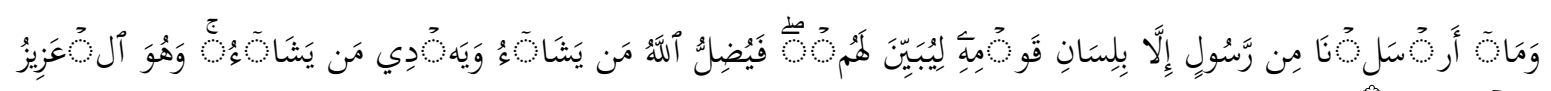
آن آنَا

Artinya: Kami tidak mengutus seorang rasulpun, melainkan dengan bahasa kaumnya, supaya ia dapat memberi penjelasan dengan terang kepada mereka. Maka Allah menyesatkan siapa yang Dia kehendaki, dan memberi petunjuk kepada siapa yang Dia kehendaki. Dan Dia-lah Tuhan Yang Maha Kuasa lagi Maha Bijaksana. ${ }^{16}$

Makna bilisani qaumihi pada ayat di atas adalah suatu upaya untuk menyampaikan, menerjemahkan dan menafsirkan ajaran Islam dengan memahami dan mengapresiasi konteks psikologis, sosial, ekonomi, demografis dan kondisi objektif dari sasaran dakwah. Bahasa dakwah harus lekat dengan konteks sejarah dan kultural masyarakatnya, karena mereka lahir dari orang tua, ras, tanah air, jenis kelamin dan latar belakang sosial tertentu. Karena itu, komunikasi dalam dakwah membutuhkan pendekatan dan metode-metode khusus untuk menafsirkan dan menyampaikan kebenaran Islam dalam dimensi ruang dan waktu yang menjadi tempat bagi masyarakat untuk berada.

Dalam prakteknya, kulturalisasi dakwah yang dilakukan da'i-da'i Muhammadiyah di Kabupaten Tapanuli Selatan adalah membahasakan dakwah sesuai dengan kebutuhan masyarakat lokal tanpa bertentangan dengan prinsip ajaran Islam. Para dai yang bertugas selama ini telah berupa keras mempelajari bahasa dan budaya masyarakat Tapanuli Selatan untuk menyebarluaskan ajaran Islam kepada masyarakat lokal. Kegiatan pesta adat yang berlangsung di tengah masyarakat tidak secara tegas ditolak atau dilarang oleh tokoh-tokoh atau dau Muhamamdiyah. Mereka mengikutinya sepanjang tidak bertentangan dangan ajaran pokok Islam.

Di luar anggota Muhammadiyah, terdapat masyarakat Islam di Kabupaten Tapanuli Selatan yang sangat longgar melaksanakan pengamalan agama. Ini menjadi lahan dakwah kultural Muhammadiyah di Kabupaten Tapanuli Selatan yang secara perlahan-lahan dimotivasi dan diarahkan agar masyarakat Muslim di daerah ini dapat membedakan mana ajaran Islam yang murni dan mana adat istiadat yang harus dipisahkan dari agama.

Masyarakat etnis Batak dikenal sebagai etnis yang development minded, seperti motivasi dan inovasi yang kuat untuk meningkatkan pendapatannya, bersedia mencari kesempatan peluang untuk maksud tersebut, sanggup pula belajar mengeksploitasi tiap kesempatan yang ada ${ }^{17}$. Di samping itu, sejak dahulu masyarakat Tapanuli Selatan hidup dalam suasana gotong royong yang dalam

${ }^{16}$ Ibid, h. 379

${ }^{17}$ Lihat penjelasan David Harry Penny " The Transition From Subsistence to Commercial Family Farming in North Sumatera", Doctoral Thesis. Cornell University, 1964, h. 28-38 
bahasa Batak disebut marsialapari (saling tolong-menolong) dalam suatu kelompok komunitas. Kegiatan gotong royong yang dilakukan oleh kelompok ini adalah dalam mengerjakan ladang maupun sawah. Anggota-anggotanya terdiri dari lima hingga delapan orang. Masing-masing anggota kelompok ini tidak menerima upah, dan tiap-tiap pekerjaan akan dilakukan secara bergilir di tiap-tiap ladang atau sawah anggota kelompok. Sistem ini bukan hanya dimanfaatkan untuk bekerja di sawah atau perladangan, namun juga untuk kepentingan hal-hal lain, sesuai dengan perjanjian yang ditentukan bersama oleh kelompok itu sendiri.

Gambaran kultur masyarakat Tapanuli Selatan di atas merupakan potensi sekaligus tantangan bagi para dai Muhamrnadiyah untul melaksanakan kegiatan dakwah. Dikatakan sebagai potensi, karena prinsip gotong royong dan bekerjasama yang telah tertanam dalam tradisi Tapanuli Selatan bukan hanya menjadi tujuan dakwah, tetapi juga menjadi sumberdaya potensial untuk memaksimasi aktivitas dakwah. Dai tidak terlalu sulit untuk mengajak masyarakat membersihkan masjid secara gotong royong, membangun prasarana jalan dan sebagainya yang dapat dimanfaatkan untuk kemakmuran dan kemaslahatan umat. Dikatakan menjadi tantangan apabila dai tidak memiliki kreatifitas membangun dan memberdayakan potensi yang dimiliki oleh masyarakat Tapanuli Selatan tersebut.

Dalam konteks inilah dai Muhammadiyah dianggap mampu menggunakan seluruh potensi sumberdaya dan akar kultur yang melekat dalam kehidupan masyarakat Tapanuli Selatan, untuk selanjutnya dimaksimasi penggunaannya dalam aktivitas dakwah. Kegiatan dakwah kultural semacam ini menuntut adanya kemampuan merasa dan kemampuan memanej kebutuhan (social needs) dan ketertarikan (social interests) masyarakat Tapanuli Selatan untuk berpartisipasi dalam kegiatan dakwah.

Sejak awal kehadirannya, organisasi Muhammadiyah telah bekerja dengan segala daya dan kemampuan untuk mencerdaskan kehidupan bangsa dan mempraktekkan ajaran Islam. Sebagai gerakan tajdid, orientasi dakwah Muhammadiyah meliputi prufikasi dan dinamisasi. Purifikasi dimaksudkan sebagai usaha pemurnian yang diarahkan pada hal-hal yang prinsip dalam ajaran Islam terutama dalam bidang akidah, ibadah dan akhlak. Dinamisasi adalah aktualisasi Islam terutama dalam muamalah bagi pemecahan persoalan kehidupan sosial, pendidikan, ekonomi, budaya dan politik umat secara praktis ${ }^{18}$.

Namun sayangnya di Kabupaten Tapanuli Selatan, aktualisasi Islam dalam bidang ekonomi kurang begitu berkembang. Hal ini dapat dilihat dari hampirhampir tidak ditemukannya lembaga ekonomi yang dikelola baik oleh pengurus 
ranting, cabang maupun daerah. PDM Kabupaten Tapanuli Selatan pernah mengelola koperasi, namun menurut Sekretaris Daerah PDM Kabupaten Tapanuli Selatan (Drs. Lazuardi, M.Ag.) karena keberadaannya kurang begitu berkembang pada saat ini koperasi tersebut ditutup.

Mengenai sarana pendidikan yang dikelola Muhammadiyah dapat dikatakan sangat menggembirakan di Kabupaten Tapanuli Selatan, selain TK Aisyiyah, Sekolah Dasar dan SMP Muhammadiyah yang tidak hanya di ibukota Kabupaten (Padangsidimpuan), tetapi juga ditemukan di kecamatan-kecamatan Tapanuli Selatan. Apalagi pada jenjang pendidikan tinggi, dengan adanya Universitas Muhammadiyah Tapanuli Selatan (UMTS) dapat dikatakan organisasi 'Muhammadiyah di Tapanuli Selatan selangkah lebih maju dan menunjukkan kepeduliannya terhadap peningkatan sumberdaya manusia masyarakat Tapanuli Selatan.

\section{c. Metode dakwah bil hal}

Selain metode dakwah yang telah diuraikan di atas, dakwah Muhammadiyah di Kabupaten Tapanuli Selatan juga menggunakan pendekatan dakwah bil hal. Dakwah bil hal merupakan dakwah dalam bentuk tindakan nyata perbuatan maupun pembangunan. Dakwah bil-hal merupakan kegiatan dakwah yang tidak hanya berbicara tetapi berbuat secara nyata bersama masyarakat, sehingga secara konkrit apa yang menjadi masalah dalam masyarakat dapat diselesaikan. Metode ini kelihatannya lebih efektif dan berkesan jika dibandingkan dengan metode lainnya, karena masyarakat tidak hanya diajar dengan teori, tetapi lebih jauh dari itu telah dipraktekkan oleh para dal tersebut, sehingga hasilnya dapat lebih mencapai tujuan yang diharapkan.

Menurut Quraish Shihab, alternatif dakwah bil hal berangkat dari asumsi bahwa syarat utama agar suatu komunitas dapat memelihara dan mengembangkan identitasnya adalah terciptanya kondisi yang tergorganisasi, yang kemudian memudahkan persatuan, kerjasama, dan pergerakan ke arah yang lebih produktif ${ }^{19}$.

Dakwah bil hal Muhammadiyah di Kabupaten Tapanuli Selatan berupaya mengatasi kebutuhan dan kepentingan anggotanya, khususnya dalam bidang ekonomi, pendidikan dan kesehatan. Dalam bidang ekonomi, pengurus Muhammadiyah berupaya membantu kegiatan usaha anggota dengan jalan memberi pinjaman modal baik secara pribadi maupun bersama-sama. Himpitan ekonomi warga Muhammadiyah di Kabupaten Tapanuli Selatan dapat teratasi dengan cara sating bantu dan tolong menolong. Metode dakwah bil hal

${ }^{19}$ M. Quraisy Shihab, Membumikan Al-Qur'an, Fungsi dan Peran Wahyu dalam Kehidupan Masyarakat (Bandung: Mizan, 1992), h. 398. 
Muhammadiyah di Kabupaten Tapanuli Selatan juga terealisasi melalui lembaga pendidikan yang dimilikinya, melaksanakan dakwah melalui peningkatan kualitas sumber daya manusia.

\section{Efektifitas Pelaksanaan Metode Dakwah Muhammadiyah di Kabupaten Tapanuli Selatan}

Prioritas penggunaan metode dakwah perlu mempertimbangkan sasaran serta luasnya ruang lingkup kegiatan dakwah serta memperhatikan dan mempelajari kondisi, latar belakang ekonomi, pendidikan maupun sosio kultural masyarakat yang menjadi objek dakwah. Berdasarkan itu, pelaksanaan dakwah harus memperkirakan serta mempertimbangkan secara rasional unsur-unsur kekuatan, kelemahan, kesempatan serta tantangan yang ada.

Melalui perumusan analisis yang tajam menyangkut kondisi realistis ini, maka dibutuhkan penerapan metode dakwah yang akurat. Perencanaan penerapan berbagai metode oleh pelaksana kegiatan dakwah, baik dai maupun pengurus Muhammadiyah di Kabupaten Tapanuli Selatan diperkirakan akan mendatangkan hasil yang maksimal. Dalam subbab ini akan dibahas beberapa hambatan pelaksanan dakwah di Kabupaten Tapanuli Selatan serta kendala-kendala penerapan metode serta upaya antisipasinya.

Menurut penuturan salah seorang anggota Muhammadiyah yang aktif mengikuti kegiatan dakwah di majelis taklim Muhammadiyah, penggunaan metode ceramah dan diskusi yang berlangsung selama ini cukup efektif meningkatkan pengetahuan dan pemahaman agama peserta pengajian. Materi ceramah selalu mengacu kepada Alquran dan hadis, kemudian diberikannya peluang kepada peserta untuk berdiskusi jawab) mengenai berbagai persoalan yang tidak dimengerti. Namun demikian tidak berarti penggunaan metode oral communication seperti ini tidak menuai masalah. Menurut peserta pengajian, penggunaan metode ceramah ini terkesan sangat monoton dan kaku dalam penyampaiannya.

Dilihat dari aspek pekerjaan masyarakat yang umumnya berprofesi sebagai petani, umumnya mereka dapat berkumpul (mengikuti ceramah agama) pada malam hari di atas pukul 20.00. Ini menjadi kendala tersendiri mengingat waktu pelaksanaan dakwah relatif singkat. Dengan demikian penggunaan metode dakwah ceramah dan diskusi relatif kurang maksimal menyentuh kebutuhan masyarakat lokal di Kabupaten Tapanuli Selatan.

Penerapan metode dakwah kultural Muhanimadiyah di Kabupaten Tapanuli Selatan dianggap sebagai salah satu bentuk penyelenggaraan alternatif dakwah di masa depan. Dengan mempelajari kondisi sosio budaya, adat istiadat dan kultural masyarakat setempat, dakwah dapat berjalan tanpa hams mengumpulkan massa yang banyak. Dakwah dapat dilakukan dimana saja dan kapan saja. Ini berarti 
menuntut kesiapan dai dalam memahami bahasa, budaya, latar belakang ekonomi, pendidikan, psikologi, dan adat istiadat masyarakat setempat. Selain itu, metode dakwah kultural menuntut kesiapan banyak orang yang terlibat, yang tidak terfokus pada dai. Semua anggota Muhammadiyah di Kabupaten Tapanuli Selatan dapat berfungsi sebagai dai untuk merubah tatanan kehidupan masyarakat yang tidak baik menjadi lebih baik.

Didukung oleh dana yang memadai serta kecakapan yang profesional, pelaksanaan dakwah kultural Muhammadiyah di Kabupatel't Tapanuli Selatan dimungkinkan terus dapat terus terlaksana di masa depan. Selain dalam bentuk perubahan sosio budaya, bidang garapan dakwah kultural ini juga melingkupi pembenahan sistem manajemen organisasi, peningkatan sumberdaya manusia, pemberian pelayanan kesehatan bagi masyarakat Muslim, penguasaan akses-akses ekonomi dan menyediakan sarana pendidikan yang memadai di Kabupaten Tapanuli Selatan.

Untuk memberi jalan keluar terhadap kendala pelaksanaan dakwah serta penggunaan metode dakwah yang efektif di Kabupaten Tapanuli Selatan perlu dipikirkan alternatif antisipasi. Upaya yang dilakukan oleh PDM Kabupaten Tapanuli Selatan untuk mengatasi sulitnya medan dakwah di Kabupaten Tapanuli Selatan adalah dengan memberikan sarana transportasi dan intensif bagi para dai Muhammadiyah yang bertugas di desa-desa terpencil agar termotivasi dan serius menjalankan aktivitas dakwah. Selain itu, PDM Kabupaten Tapanuli Selatan juga concern menggalang kerjasama dengan berbagai ormas Islam di Kabupaten Tapanuli Selatan maupun dengan pemerintah Kabupaten Tapanuli Selatan yang secara sistematis dan terprogram menyelenggarakan dakwah di daerah ini. Seiring dengan kebutuhan masyarakat di desa-desa yang jauh dari ibukota kecamatan terhadap dai, maka PDM Kabupaten Tapanuli Selatan merencanakan akan mengirim dai-dai untuk tinggal menetap di desa-desa yang membutuhkan penyuluh dan pembimbing agama. Untuk mewujudkan rencana ini, dibutuhkan dana yang tidak sedikit dan seleksi bagi calon-calon dai yang akan diterjunkan di desa-desa.

\section{Pembahasan}

Sebagai suatu pelembagaan nilai-nilai Islam dalam prosesnya, dakwah bertumpu kepada sistem yang terdiri dari berbagai komponen atau unsur dakwah, yaitu dai, materi, penerima, media, metode dan efek dakwah. Keseluruhan unsur dakwah ini saling mempengaruhi dan melengkapi dalam rangka mewujudkan tujuan dakwah.

Selain itu, kompoenen dakwah juga terdiri dari input, output, convergensi, feedback dan environment. 
1. Komponen input (masukan) yang terdiri dari rawl input, instrument input dan environmental input yang kesemuanya berfungsi memberikan informasi, energi dan materi yang menentukan eksistensi sistem.

2. Konvergensi berfungsi untuk mengubah input menjadi output, merealisiir ajaran Islam menjadi realitas sosial kultural yang diproses dalam kegiatan administrasi dakwah (organisasi, managemen, kepemimpinan, komunikasi dakwah dan lainlain) .

3. Komponen output (keluaran) yang merupakan hasil dakwah yaitu terciptanya realitas baru menurut ukuran tujuan ideal dan tujuan antara dari sistem dakwah yang bersumber dari Alquran.

4. Komponen feedback (umpan balik) yang berungsi memberikan pengaruh baik positif maupun yang negatif terhadap sistem dakwah khususnya dan realitas sosio kultural pada umumnya.

5. Komponen lingkungan yang berfungsi sebagai kenyataan yang hendak diubah (sasaran) atau memberikan pengaruh terhadap sistem dakwah terutama memberikan masukan permasalahan yang perlu dipecahkan yang menyangkut ideologi, politik, pendidikan, ekonomi, teknologi, ilmu, seni dan sebagainya.

Manakala dikaji lebih mendalam dapat dipahami bahwa sistem dakwah yang dibentuk sebagai suatu keseluruhan memiliki fungsi mengubah lingkungan secara lebih terperinci yang meliputi fungsi:

1. Meleletakkan dasar eksistensi masyarakat Islam;

2. Menanamkan nilai keadilan, persamaan, sebagai inti penggerak perkembangan masyarakat;

3. Membebaskan individu dan masyarakat dari sistem kehidupan yang zalim (tirani, totaliter) menuju sistem kehidupan yang adil;

4. Memberikan kritik social atas penyimpangan yang berlaku dalam masyarakat dalam rangka mengemban tugas "nahy munkar" dan memberikan alternatif konsepsi atas kemacetan sistem dalam rangka melaksanakan Islam sebagai inti penggerak sejarah masa depan umat;

5. Memberikan dasar orientasi keislaman bagi kegiatan ilmiah dan teknologi;

6. Merealisir sistem budaya yang berakar pada dimensi spiritual yang merupakan ekspresi akidah (teologis);

7. Meningkatkan kesadaran masyarakat untuk menegakkan hukum;

8. Mengintegrasikan kelompok-kelompok kecil menjadi suatu kesatuan umat.

9. Merealisir keadilan dalam bidang ekonomi dengan membela kelasmasyarakat yang berekonomi lemah (fakir miskin) dan member kerangka dasar keselarasan hubungan manusia dengan alam lingkungannya. 
Kerangka pikir di atas patut menjadi perhatian untuk menjalankan fungsi dari sistem dakwah sebagai upaya perkembangan nilai-nilai Islam di Kabupaten Tapanuli Selatan. sebab perintah Allah untuk masuk ke dalam Islam secara kaffah merupakan tuntutan ideal dari Islamisasi kehidupan secara menyeluruh. Allah berfirman dalam surah al-Baqarah ayat 208:

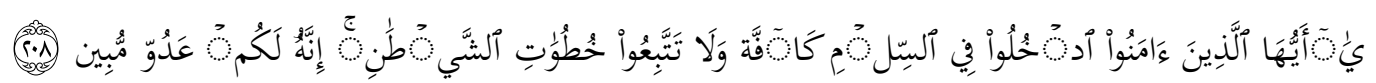
Artinya: "Hai orang-orang beriman, masuklah kamu ke dalam Islam keseluruhannya, dan janganlah kamu turut langkah-langkaah syeitan, sesungguhnya syeitan itu musuh yang nyata bagimu" 20 .

Dengan demikian yang dilembagakan dalam masyarakat melalui dakwah adalah nilai-nilai Islam, sehingga masyarakat benar-benar terbentuk menjadi masyarakat Islami. Dengan kata lain, dakwah yang sedang dan akan terus berlangsung di Kabupaten Tapanuli Selatan merupakan proses internalisasi dan tranformasi syariat Islam agar secara individual dan masyarakat dapat melaksanakan ajaran Islam dalam seluruh aspek kehidupannya.

Syariat Isiam merupakan hukum Tuhan untuk manusia. Dalam rangka memberikan tuntunan dan tuntutan moral dalam upaya menyelamatkan manusia agar tumbuh dan berkembang sesuai dengan fitrahnya. Dalam hal ini hukum ialah normanorma yang menentukan bagaimana anggota-anggota masyarakat berlaku dan berbuat. Keberadaan norma atau kaidah agama merupakan petunjuk tentang perbuatan mana yang patut dilakukan dan perbuatan mana yang mesti ditinggalkan. Syariat sebagai nilainilai Islam menggariskan suruhan dan larangan, yang disuruh adalah yang bernilai, sedangkan yang dilarang adalah yang merusak nilai. Untuk itulah, fungsi dakwah berorientasi kepada penerapan kerangka berpikir kritis dalam persoalan-persoalan dakwah, sehingga pelembagaan nilai-nilai ajaran Islam dalarn perilaku individu dan masyarakat di Kabupaten Tapanuli Selatan dapat berlangsung secara berkesinambungan.

\section{KESIMPULAN}

Berdasarkan pembahasan sebelumnya, maka dapat ditarik beberapa kesimpulan sebagai berikut:

1. Metode dakwah Muhammadiyah yang dilakukan oleh dai Muhammadiyah di Kabupaten Tapanuli Selatan masih bertumpu pada metode dakwah bil lisan. Selain itu, juga diterapkan metode dakwah kultural serta metode dakwah bil hal. Penyelenggaraan metode ceramah terkesan monoton dan kurang memiliki daya tarik. Di samping itu metode dakwah ceramah membutuhkan sejumlah orang, tempat dan waktu. Ini menimbulkan masalah bagi masyarakat yang mayoritas petani

${ }^{20}$ Departemen Agama RI, Al-Qur'an dan ..., h.50. 
dan praktis hanya memiliki waktu senggang mengikuti pengajian di malam hari di atas pukul 20.00. Oleh sebab itu dibutuhkan pendekatan yang lebih mampu memberikan jalan keluar bagi penyelenggaraan dakwah di Kabupaten Tapanuil Selatan. Tampaknya pendekatan dakwah kultural sangat tepat diterapkan untuk menyebarluaskan ajaran Islam di tengah masyarakat Muslim Kabupaten Tapanuli Selatan.

2. Pelaksanaan dakwah di Kabupaten Tapanuli Selatan menemukan beberapa hambatan. Antara lain adalah kondisi aiam yang berada di daerah pegunungan; letak satu desa dengan desa lainnya berjauhan; faktor adat istiadat yang demikian menyulitkan dai-dai Muhammadiyah melaksanakan aktivitas dakwah di daerah ini. Antisipasi yang dilakukan adalah memberikan fasilitas kenderaan roda dua bagi dai agar dapat bertugas hingga ke pelosok desa, memberikan intensif yang memadai bagi para dai, melakukan kerjasama dengan ormas/lembaga dakwah Islam lainnya serta pemerintah Kabupaten Tapanuli Selatan untuk merancang sistem pelaksanaan dakwah yang lebih baik. Selain itu, PDM Kabupaten Tapanuli Selatan merencanakan mengirim sejumlah dai untuk menetap di desa-desa yang membutuhkan tenaga penyuluh dan pembimbing keagamaan masyarakat Muslim. 


\section{DAFTAR RUJUKAN}

Ahmad, Amrullah (ed). Dakwah Islam dan Transfortnasi Sosial Budaya. Yogyakarta: PLP2M, 1985.

Ahmad, Amrullah. Dakwah Islam dan Perubahan Sosial. Yogyakarta: Prima Duta, 1989.

Al-Faruqi, Isma'il R. dan Lois Lamya Al-Faruqi, Atlas Budaya Islam Menielajah Khazanah Peradaban Gemilang, diterjemahkan oleh Ilyas Hasan. Bandung: Mizan, 2000.

Anggaran Dasar \& Rumah Tangga Muhammadiyah. Hasil Keputusan Muktamar Muhammadiyah ke-45 Malang-lawa Timur (3-8 Juli 2005).

Azra, Azyumardi. Islam Reformis Dinamika Intelektual dan Gerakan. Jakarta: Raja Grafindo Persada, 1999.

Badan Pusat Statistik Kabupaten Tapanuli Selatan, Kabupaten Tapanuli Selatan dalam Angka Tahun 2004. Padangsidimpuan: BPS Kabupaten Tapanuli Selatan, 2004.

Bangun, Payung. "Kebudayaan Batak", dalam Koentjaraningrat, Manusia dan Kebudayaan di Indonesia. Jakarta: Djambatan, 1985.

Bappeda Kabupaten Tapanuli Selatan. Pemetaan Lahan Budidaya Pertanian Kabupaten Tapanuli Selatan. Padangsidimpuan: Kerjasama antara Bappeda Kabupaten Tapanuli Selatan dengan LPPM USU, 2003.

Basyaib, Hamid dan Hamid Abidin (ed). Mengapa Partai Islam Kalah? Perjalanan Politik Islam dari Pra-Pemilu'99 sampai Pemilihan Presiden. Jakarta: Alvabet, 1999.

Daulay, Haidar Putra dkk. Potensi dan Pembinaan Generasi Muda di Tapanuli Selatan. Padangsidimpuan: Balai Penelitian IAIN Sumatera Utara, 1993.

Departemen Agama RI. Al-Qur'an dan Terjemahnya. Semarang: Toha Putra, 1989.

Departemen Pendidikan dan Kebudayaan RI. Kamus Besar Bahasa Indonesia. Jakarta: Balai Pustaka, 1995.

Echols, Juhn M. dan Hassan Shadily. Kamus Inggris Indonesia. Jakarta: Gramedia, 1979.

Gibb, H.A.R. Modern Trends in Islam. Beirut: Librairie du Liban, 1975.

Hamka. Tafsir Al-Azhar. Jakarta: Pustaka Panji Mas, 1983.

Harahap, Syahrin. Islarn Konsep dan Implementasi Pemberdayaan. Yogyakarta: Tiara Wacana Yogya, 1999.

Harahap, Syahrin. Membangun Tapanuli Selatan Serambi Mekkah Inklusif dan Modern. Jakarta: Yayasan Al-Mukhtariyah, 2004. 
Hasjmy, A. Dustur Dakwah Menurut Al-Qur'an. Jakarta: Bulan Bintang, 1994.

Koentjaraningrat. Kebudayaan Mentalitet dan Pembangunan. jakarta: Gramedia, 1974.

Miles, Matthew dan A. Michel Huberman. Analisis Data Kualitatif. Jakarta: UI Press, 1992.

Musa, M. Yusuf. Alquran dan Falsafah, terjemahan Ahmad Daudy, Jakarta: Bulan Bintang, 1988.

Nawawi, Hadary dan Mimi Martini. Penelitian Terapan. Yogyakarta: Gadjah Mada University Press, 1996.

Omar, Thoha Yahya. Ilmu Dakwah. Jakarta: Wijaya, 1983.

Parlindungan, M.O. Tuanku Rao. Jakarta: Tanjung Pengharapan, 1964.

Peacock, James L. Gerakan Muhammadiyah Memurnikan Ajaran Islam. Jakarta: Citra Kreatif, 1986.

Penny, David Harry. "The Transition From Subsistence to Commercial Family Farming in North Sumatra", Doctoral Thesis. Cornell University, 1964.

Pimpinan Pusat Muhammadiyah. Anggaran Dasar dan Anggaran Rumah Tangga Muhammadiyah. Yogyakarta: PP. Muhammadiyah, 2002.

Pimpinan Pusat Muhammadiyah. Dakwah Kultural Muhammadiyah. Yogyakarta: Suara Muhammadiyah, 2004.

Pratiknya, A. Watik. "Konsep dan Strategi Dakwah Kultural Muhammadiyah", Makalah Seminar Antarbangsa Pengajian Dakwah Malaysia-Indonesia, Medan, 18 Mei 2002.

Puar, Yusuf Abdullah. Perjuangan dan Pengabdian Muhammadiyah. Jakarta: Pustaka Antara, 1989.

Rais, M. Amien. Cakrawala Islam Antara Cita dan Fakta. Bandung: Mizan, 1989.

Shaleh, Abd. Rosyad. Manajemen Dakwah Islam. Jakarta: Bulan Bintang, 1977.

Shihab, M. Quraish. Membumikan Al-Quran, Fungsi dan Peran Wahyu dalam Kehidupan Masyarakat. Bandung: Mizan, 1992.

Solissa, Abdul Basir, dkk. (ed). Alquran dan Pembinaan Budaya Dialog dan Transformasi, Youakarta: Lembaga Studi Filsafat Islam, 1993.

Sulthon, Muhammad. Menjawab Tantangan Zaman Desain Ilmu Dakwah, Kaiian Ontologis,

Epistemologis dan Aksiologis. Yogyakarta: Kerjasama Pustaka Pelajar dengan Walisongo Press, 2003.

Suparta, Munzier dan Harjani Hefni. Metode Dakwah. Jakarta: Rahmat Semesta, 2003.

Syukir, Asmuni. Dasar-Dasar Strategi Dakwah Islam. Surabaya: Al-Ikhlas, 1983. 
50 Tazkir Vol. 02 No. 1 Januari - Juni 2016

Tasmara, Toto. Komunikasi Dakwah. Jakarta: Gaya Media Pratama, 1997.

Ya'cub, Hamzah. Publisistik Islam Teknik Dakwah dan Leadership. Bandung: Diponegoro, 1992.

Yaqan, Fathin. Menuju Kepada Islam, diterjemahkan Chadijah Nasution. Jakarta: Bulan Bintang, 1978.

Yunus, Mahmud. Pedoman Dakwah Islamiyah. Jakarta: Hidakarya Agung, 1973. 